MINERALOGIA POLONICA

DOI 10.2478/v10002-007-0017-6

PL ISSN 0032-6267

Vol. 38, No 1, 2007

Elena G. BALAGANSKAYA ${ }^{1}$, Hilary DOWNES ${ }^{2}$, Daniel DEMAIFFE ${ }^{3}$

\title{
REE AND Sr-Nd ISOTOPE COMPOSITIONS OF CLINOPYROXENITES, PHOSCORITES AND CARBONATITES OF THE SEBLYAVR MASSIF, KOLA PENINSULA, RUSSIA
}

\author{
Received November 11, 2006; accepted September 13, 2007
}

A b st r a ct. Clinopyroxenites, phoscorites and carbonatites from the Devonian Seblyavr intrusion (Kola Peninsula, Russia) have petrographic characteristics indicating that they are accumulative in origin. Their geochemical (major and rare earth elements) compositions can be accounted for by mixtures of their major rock-forming minerals and accessory phases, i.e. they reflect the record of mineral accumulation. All of the analysed Seblyavr rocks are strongly LREE-enriched with $(\mathrm{La} / \mathrm{Yb})_{\mathrm{N}}$ mostly ranging from 38 to 189 . However, a dolomite carbonatite with hydrothermal LREE-Sr mineralization has an extreme $(\mathrm{La} / \mathrm{Yb})_{\mathrm{N}}$ value of 1659 . Such late-stage dolomite carbonatites were formed by hydrothermal (rather than magmatic) processes. Whole-rock samples of representative magmatic lithologies from Seblyavr have initial ${ }^{87} \mathrm{Sr} / 86 \mathrm{Sr}$ and $\varepsilon_{\mathrm{Nd}}$ that fall in a very narrow range from 0.7031 to 0.7033 and +4.9 to +5.9 , respectively. We therefore conclude that clinopyroxenites, phoscorites and carbonatites were formed by differentiation and crystallization of a single batch of melt. The parental melt was derived from a depleted upper mantle source that had been metasomatised prior to melting.

Key-words: Seblyavr, clinopyroxenite; carbonatite, phoscorite, Kola Peninsula

\section{INTRODUCTION}

Studies of carbonatites and coeval silicate rocks can provide insights into the processes that produce their contrasting magma types. The Kola Alkaline Carbonatite Province (KACP) is a region of Devonian magmatism in NW Russia where both alkaline-ultramafic and carbonatitic magmatism was well developed (Woolley 1989; Kogarko et al. 1995; Downes et al. 2005). More than 20 massifs composed of alkaline and

1 Geological Institute, Kola Science Centre, 14 Fersman St., Apatity, Murmansk Region, 184200, Russia.

2 School of Earth Sciences, Birkbeck University of London, Malet St., London WC1E 7HX, UK.

3 Géochimie Isotopique, CP 160/02, Université Libre de Bruxelles, 50 Av. Roosevelt, 1050 Brussels, Belgium. 
ultramafic rocks occur in the KACP, and sixteen of them contain carbonatites (Fig. 1). To extend our understanding of the petrogenesis of coexisting alkaline and carbonatitic magmas, we undertook a study of Seblyavr, the northernmost intrusive complex in the KACP (Fig. 1). This paper presents the results of a study on the mineralogy and geochemistry (major elements, REE, Sr and Nd isotopes) of the main types of intrusive silicate rocks and phoscorite-carbonatites of Seblyavr.

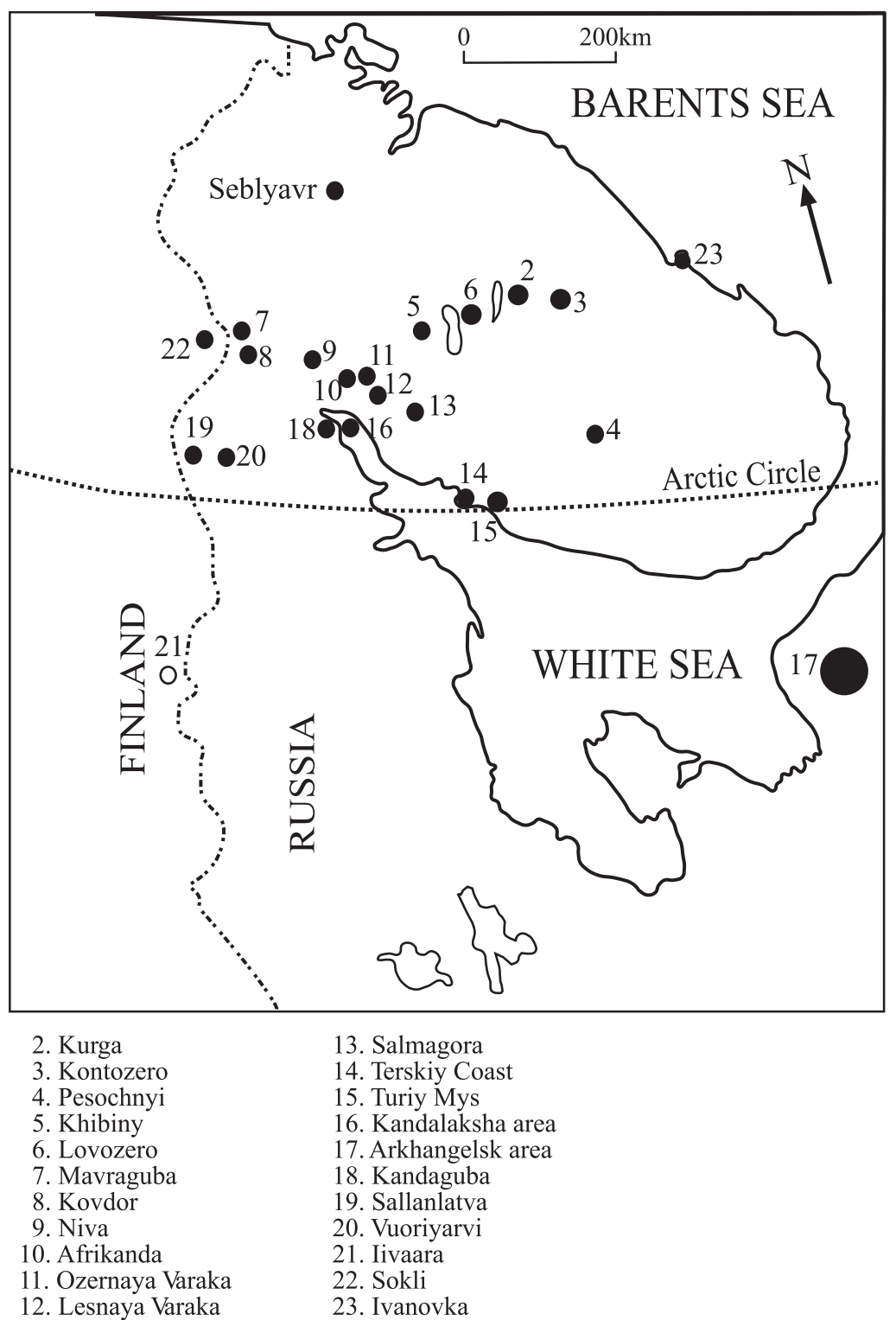

Fig. 1. Location map for Palaeozoic alkaline and ultramafic-alkaline massifs in the Kola region 


\section{GENERAL GEOLOGY OF THE SEBLYAVR MASSIF}

The Seblyavr massif is located in the north-western part of the KACP $\left(68^{\circ} 43^{\prime} \mathrm{N}\right.$, $32^{\circ} 08^{\prime} \mathrm{E}$ ). It is poorly exposed and is composed largely of clinopyroxenites, as well as ijolites, phoscorites and carbonatites [see Downes et al. (2005) for definitions of rock-types in the KACP]. Data on its structure and composition, provided by numerous boreholes and geophysical studies, were summarized by Bulakh and Abakumova (1960), Kukharenko et al. (1965) and Lapin (1979). Cross-cutting relations show the sequence of intrusions (Table 1) and demonstrate that the phoscorites and carbonatites were intruded during four successive stages and form a concentric network of dykes and veins cross-cutting the clinopyroxenites. Samples for geochemical investigations (Table 2) were collected entirely from borehole cores and represent the main rock-types. They display almost no alteration.

TABLE 1

Sequence of main rocks types formation and stages of phoscorites and carbonatites of the Seblyavr massif, based on the data of Subbotin (1998) and the authors' observations

\begin{tabular}{llcc}
\hline \multicolumn{1}{c}{ Rock } & Index & Age \\
\hline Olivinites & & & \\
\hline Peridotites & & & \\
\hline Clinopyroxenites & & $410+/-7^{*}$ \\
\hline Ijolites & \multicolumn{1}{l}{ Apatite-phlogopite-diopside-magnetite phoscorite } & Ph I & \\
\hline Phoscorite-carbonatite complex & C I & $408+/-7^{* *}$ \\
\hline \multirow{2}{*}{ I stage } & Diopside-amphibole-phlogopite-calcite carbonatite & Ph II & $378+/-4^{* * *}$ \\
\hline \multirow{2}{*}{ II stage } & Apatite-forsterite-magnetite phoscorite & C II & $376+/-6^{* * * *}$ \\
\cline { 2 - 5 } & Phlogopite-calcite carbonatite & Ph III & \\
\hline \multirow{2}{*}{ III stage } & Calcite-tetraferriphlogopite-magnetite phoscorite & C III & \\
\cline { 2 - 5 } & Tetraferriphlogopite-calcite carbonatite & Ph IV & \\
\hline \multirow{2}{*}{ IV stage } & Amphibole-apatite-sulphides-magnetite phoscorite & D IV & \\
\cline { 2 - 5 } & Dolomite carbonatite &
\end{tabular}

Dykes of alkaline syenites and lamprophyres

* Rb-Sr isochron for sample Sb2 (BEG-7) (WR, Clinopyroxene, phlogopite; ISr = 0.7031, MSWD = $=0.555)$, Gogol and Delenitsyn (1999).

** Rb-Sr isochron for sample Sb5 (BEG-10) (WR, Calcite, phlogopite, amphibole, apatite; ISr = 0.7031, MSWD = 1.45), Gogol and Delenitsyn (1999).

*** U-Pb age on baddeleyite from sample Sb6, Gogol et al. (1998).

**** Rb-Sr isochron for sample Sb4 ( WR, phlogopite, ISr = 0.7030), Gogol et al. (2000). 
TABLE 2

Mineralogical composition of Seblyavr rocks studied

\begin{tabular}{|c|c|c|c|c|c|c|c|c|c|c|c|c|c|c|c|}
\hline Sample & $\mathrm{Sb} 2$ & $\mathrm{Sb} 11$ & $388 / 249$ & $388 / 240$ & Sb3 & Sb6 & $388 / 236$ & Sb10 & Sb5 & $88-81$ & $91(2)-81$ & Sb4 & $\mathrm{Sb} 8$ & $\mathrm{Sb} 9$ & $388 / 269$ \\
\hline Rock index & $P R X p$ & PRXp & PRXm & PRXa & $\mathrm{Ph} \mathrm{I}$ & $\mathrm{Ph}$ II & $\mathrm{Ph}$ II & $\mathrm{Ph}$ III & C I & C I & C II & C II & C III & D IV & D IV \\
\hline Olivine & & & & & & $+++^{*}$ & & $++^{*}$ & & & & & & & \\
\hline Diopside & ++++ & ++++ & ++++ & ++++ & ++++ & & & & + & & & & & & \\
\hline Aegirine-augite & & & & & & & & & + & & & & & & \\
\hline Amphibole & + & + & & +++ & & + & ++ & + & ++ & & & + & & & \\
\hline Phlogopite & ++ & ++ & +++ & ++ & & ++ & ++ & & ++ & ++ & ++ & + & & & \\
\hline \multicolumn{2}{|c|}{ Tetraferriphlogopite } & & & & & & ++ & & & & & + & + & & \\
\hline Magnetite & ++ & ++ & +++ & + & +++ & +++ & ++++ & ++++ & + & + & + & + & + & & \\
\hline Ilmenite & & & & & & & & & & & & & + & & + \\
\hline Calcite & + & + & + & + & ++ & ++ & ++ & +++ & ++++ & ++++ & ++++ & ++++ & ++++ & & \\
\hline Dolomite & & & & & & & & & & & + & + & + & ++++ & ++++ \\
\hline \multicolumn{2}{|c|}{ REE-Sr-carbonates } & & & & & & & & & & & & + & & \\
\hline Barite & & & & & & & & & & & & + & & + & \\
\hline Apatite & + & + & + & ++ & + & +++ & +++ & +++ & ++ & ++ & + & ++ & + & & + \\
\hline Perovskite & ++ & ++ & + & + & ++ & & & & & & & & & & \\
\hline \multicolumn{2}{|c|}{ Pyrochlore group } & & & & + & & & & & & + & $\operatorname{tr}$ & $\operatorname{tr}$ & & \\
\hline U-Pyrochlore & & & & & & & & & & & & + & & & \\
\hline Baddeleyite & & & & & & + & & + & + & + & + & + & & & \\
\hline Calzirtite & & & & & + & & & & & & & & & & \\
\hline Zirkelite & & & & & + & & & & & & & & & & \\
\hline Zirconolite & & & & & & & & & & & & & + & & \\
\hline Zircon & & & & + & + & + & & + & + & & & + & + & & \\
\hline Garnet & & & & & & & & & + & & & & & & \\
\hline Titanite & & + & & & & & & & & & & & & & \\
\hline
\end{tabular}

++++: > 30 vol. \%; +++: 10-30 vol. \%; ++: 10-5 vol. \%; +: <5 vol. \%; tr - trace.

PRXp - clinopyroxenite with perovskite, PRXm - clinopyroxenite with magnetite, PRXa - clinopyroxenite with amphibole; see Table1 for others rock indexes.

* Pseudomorphed by serpentine (Sb6) and tetraferriphlogopite and serpentine aggregate (Sb10).

32 


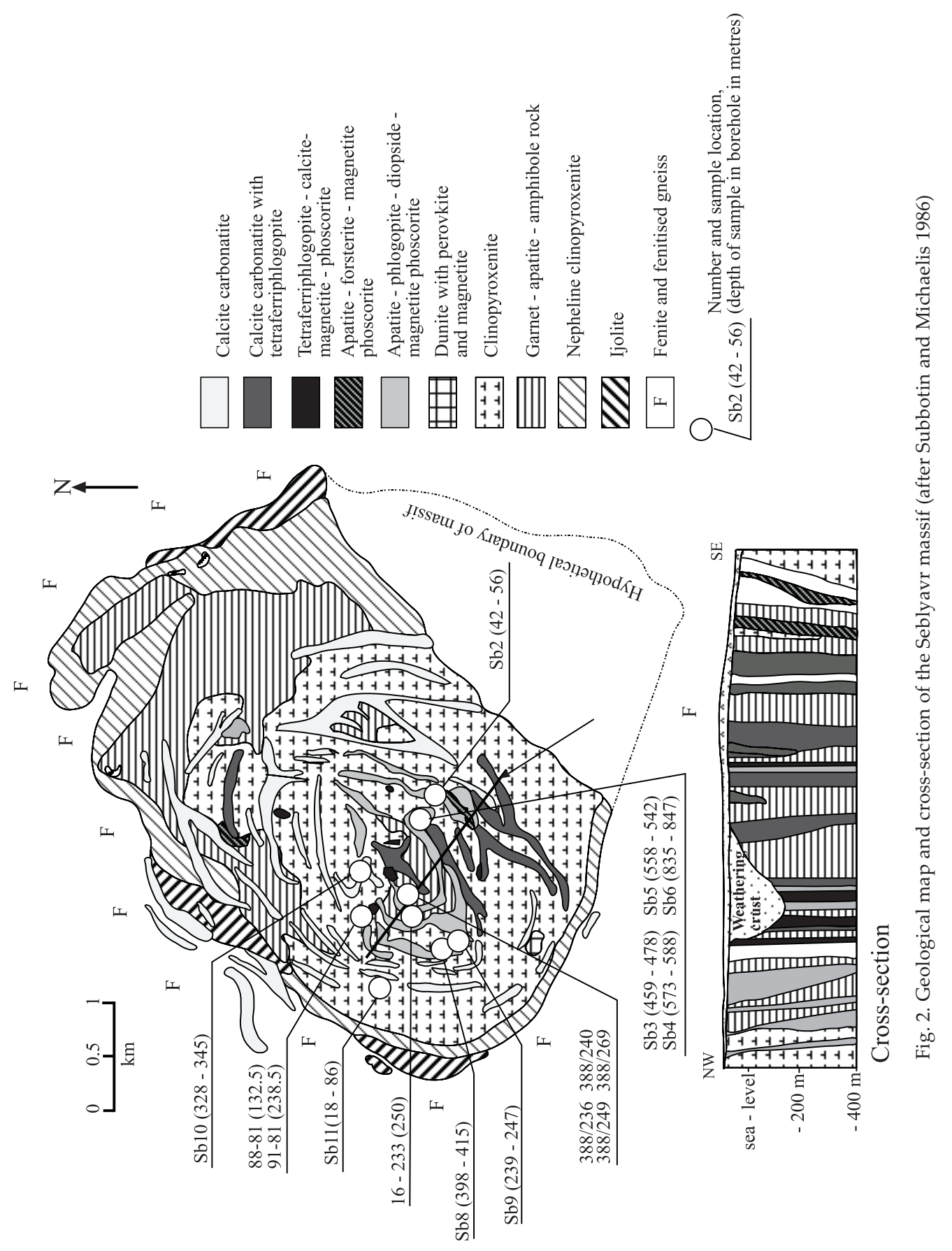


The massif is a concentrically zoned stock-like plutonic body, oval in shape, $4 \times 5 \mathrm{~km}$ in plan and with sub-vertical contacts (Fig. 2). Its core is composed of clinopyroxenites, containing blocks of "olivinites" up to $150 \mathrm{~m}$ across. Although the internationally accepted term for such rocks is "dunites", the terminology used in the KACP employs the term "olivinite" specifically for cumulates dominated by olivine (Downes et al. 2005). Clinopyroxenites are the dominant rock-type in the massif and consist of diopside, phlogopite, titanomagnetite and perovskite with subordinate amphibole, apatite and calcite (Table 2). They contain lens-like schlieren of perovskite-titanomagnetite rocks, are often metasomatically altered with growth of amphibole, phlogopite and apatite, and sometimes pass into phlogopite-clinopyroxenite, apatite-clinopyroxenite and apatite-garnet-amphibole rocks. The clinopyroxenites gradually merge into nepheline clinopyroxenites, which form a ring along the margins of the clinopyroxenitic core. Lens-like bodies of ijolite are situated between the nepheline clinopyroxenites and the country rocks, which are fenitized Archaean gneisses.

Phoscorites, defined as olivine/diopside-apatite-magnetite rocks by Tomkeieff et al. (1983) and Egorov (1993), and carbonatites were intruded during four stages (Lapin 1979; Subbotin, Mikhaelis 1986) (Table 1), although the first stage is volumetrically dominant. They form a concentric network of dykes and veins, 1-2 cm to $40-200 \mathrm{~m}$ in thickness, and stocks, up to $160 \times 300 \mathrm{~m}$, cross-cutting the clinopyroxenites (Fig. 2) and commonly revealing sharp contacts. The calcite carbonatites of earlier stages usually have outer zones $(1-3 \mathrm{~cm})$ enriched in amphibole and phlogopite and contain altered xenoliths of the wall rocks. Dykes of alkaline syenites and lamprophyres up to $1.5 \mathrm{~m}$ thick cut all the rocks of the massif. A discontinuous weathering crust covers the present day surface. It is generally a few meters thick with local depressions up to $220 \mathrm{~m}$ thick in the central area (Fig. 2).

Published Rb-Sr determinations (Gogol, Delenitsin 1999; Gogol et al. 2000) suggested that the Seblyavr clinopyroxenites have an age of $410 \pm 7 \mathrm{Ma}$, whereas phoscorite-carbonatite rocks of the first and second stages yield ages of $408 \pm 7 \mathrm{Ma}$ and $376 \pm 6 \mathrm{Ma}$, respectively (Table 1). The 410-408 Ma ages are older than most of the ages of the KACP ultramafic-alkaline-carbonatite rock complexes (Kramm et al. 1993; Kramm, Sindern 2004) and may result from minor alteration of phlogopite. A more reliable age for the Seblyavr massif $(378 \pm 4 \mathrm{Ma})$ was obtained by U-Pb analyses of baddeleyite from a second stage phoscorite (Gogol et al. 1998). This is likely to be the true age of intrusion of the later parts of the complex.

\section{ANALYTICAL METHODS}

Mineral chemistry (Table 3) was determined at Birkbeck College, University of London, by microprobe on a Cameca MS- 46 facility with accelerating voltage $22 \mathrm{kV}$, beam current 20-40 nA, 1.5-30 $\mu \mathrm{m}$ electron beam and a combination of natural and synthetic minerals as standards (GI KSC) and on a Jeol 733 Superprobe with an Oxford Instruments ISIS energy dispersive system at $15 \mathrm{kV}$ accelerating voltage and a spot diameter of $2 \mu \mathrm{m}$. 
Chemical composition of minerals

\begin{tabular}{|c|c|c|c|c|c|c|c|c|c|c|}
\hline \multirow{3}{*}{$\begin{array}{c}\text { Sample } \\
\text { Rock } \\
\text { Type }\end{array}$} & \multicolumn{2}{|c|}{ Clinopyroxene } & \multirow{3}{*}{\multicolumn{2}{|c|}{$\begin{array}{cc} & \begin{array}{c}\text { Amphi- } \\
\text { bole }\end{array} \\
\begin{array}{c}\text { Sample } \\
\text { Rock } \\
\text { Type }\end{array} & \text { Sb5 } \\
& \text { I }\end{array}$}} & \multirow{3}{*}{$\begin{array}{l}\text { Sample } \\
\text { Rock } \\
\text { Type }\end{array}$} & \multirow{3}{*}{$\begin{array}{c}\text { Sb2 } \\
\text { PRXp }\end{array}$} & \multicolumn{3}{|c|}{ Phlogopite } & \multirow{3}{*}{$\begin{array}{l}\text { Sb9 } \\
\text { D IV }\end{array}$} \\
\hline & \multirow{2}{*}{$\begin{array}{c}\text { Sb2 } \\
\text { PRXp }\end{array}$} & \multirow{2}{*}{$\begin{array}{l}\mathrm{Sb} 3 \\
\mathrm{Ph}\end{array}$} & & & & & \multirow{2}{*}{$\begin{array}{l}\text { Sb3 } \\
\mathrm{Ph} \mathrm{I}\end{array}$} & \multicolumn{2}{|c|}{$\begin{array}{l}\text { Sb10 } \\
\text { Ph III }\end{array}$} & \\
\hline & & & & & & & & core & rim & \\
\hline $\mathrm{SiO}_{2}$ & 52.09 & 53.52 & $\mathrm{SiO}_{2}$ & 56.96 & $\mathrm{SiO}_{2}$ & 38.77 & 40.93 & 41.68 & 42.74 & 39.08 \\
\hline $\mathrm{TiO}_{2}$ & 0,99 & 0.36 & $\mathrm{TiO}_{2}$ & 0.33 & $\mathrm{TiO}_{2}$ & 1.76 & 0.79 & 0.12 & 0.90 & 0.59 \\
\hline $\mathrm{Al}_{2} \mathrm{O}_{3}$ & 1.46 & 0.49 & $\mathrm{Al}_{2} \mathrm{O}_{3}$ & 0.38 & $\mathrm{Al}_{2} \mathrm{O}_{3}$ & 15.78 & 13.38 & 11.38 & 10.38 & 13.73 \\
\hline $\mathrm{Fe}_{2} \mathrm{O}_{3}$ & $1.16^{*}$ & $0.94^{*}$ & $\mathrm{FeO}$ & 5.01 & $\mathrm{FeO}$ & 7.11 & 6.95 & 3.46 & 4.32 & 4.50 \\
\hline $\mathrm{FeO}$ & $2.71^{*}$ & $2.68^{*}$ & $\mathrm{MnO}$ & 0.19 & $\mathrm{MnO}$ & 0.07 & 0.14 & 0.06 & 0.07 & 0.09 \\
\hline $\mathrm{MnO}$ & 0.10 & 0.18 & $\mathrm{MgO}$ & 21.62 & $\mathrm{MgO}$ & 23.15 & 24.52 & 26.68 & 26.61 & 24.81 \\
\hline $\mathrm{MgO}$ & 15.85 & 16.43 & $\mathrm{CaO}$ & 6.15 & $\mathrm{CaO}$ & n.a. & n.a. & 0.03 & 0.17 & 0.03 \\
\hline $\mathrm{CaO}$ & 24.89 & 24.89 & $\mathrm{Na}_{2} \mathrm{O}$ & 6.71 & $\mathrm{Na}_{2} \mathrm{O}$ & 1.59 & 1.91 & 0.51 & 0.44 & 1.43 \\
\hline $\mathrm{Na}_{2} \mathrm{O}$ & 0.45 & 0.35 & $\mathrm{~K}_{2} \mathrm{O}$ & 0.73 & $\mathrm{~K}_{2} \mathrm{O}$ & 9.28 & 8.83 & 10.03 & 10.17 & 9.12 \\
\hline Total & 99.70 & 100.01 & Total & 98.08 & Total & 97.50 & 97.46 & 94.02 & 94.89 & 94.40 \\
\hline
\end{tabular}

n.a. $=$ not analyzed,${ }^{*}-$ calculated .

Whole rock powders for geochemical analyses were prepared from $1 \mathrm{~kg}$ rock samples crushed to a grain size $<1 \mathrm{~cm}$ and homogenized to a powder. Major elements (Table 4) were analysed by wet chemistry at the Chemical Laboratory of the Geological Institute, Kola Science Centre, and by X-ray fluorescence (XRF) spectrometry (two samples of carbonatites) at the Collectif de Géochimie instrumentale, Université de Liege, Belgium. The similarities between the results for samples of calcite carbonatite CI Sb5 (analysed by wet chemical methods at Apatity) and CI 88-81 (analysed by XRF in Brussels) suggest that the data from the two laboratories are consistent. Rare earth elements were measured by (1) inductively coupled plasma emission mass spectrometry (ICP-MS) at the Département de géologie du Musée Royale de l'Afrique Centrale in Tervuren, Belgium, and (2) inductively coupled plasma atomic spectroscopy (ICP-AES) at Royal Holloway, University of London (Table 5). Both laboratories also measured their own "in-house" standards. Unfortunately, no attempt was made to check for interlaboratory consistency between these two methods, so it is possible that the two REE data sets are not comparable. However, the similarity of the chondrite-normalized patterns for most of the samples (except the hydrothermally altered sample $\mathrm{Sb9}$ ) strongly suggests that the data are consistent. 
TABLE 4

Major element composition (wt\%) of silicate rocks and carbonatites from Seblyavr

\begin{tabular}{|c|c|c|c|c|c|c|c|c|c|c|c|}
\hline Sample & $\mathrm{Sb} 2$ & Sb11 & Sb3 & Sb6 & Sb10 & Sb5 & $88-81$ & $91(2)-81$ & $\mathrm{Sb} 4$ & Sb8 & Sb9 \\
\hline & 1 & 1 & 1 & 1 & 1 & 1 & 2 & 2 & 1 & 1 & 1 \\
\hline $\begin{array}{l}\text { Rock } \\
\text { Type }\end{array}$ & $P R X p$ & PRXp & $\mathrm{Ph} \mathrm{I}$ & $\mathrm{Ph}$ II & $\mathrm{Ph}$ III & C I & C I & C II & C II & C III & D IV \\
\hline $\mathrm{SiO}_{2}$ & 30.00 & 33.04 & 22.43 & 16.40 & 5.60 & 3.33 & 4.99 & 0.93 & 3.95 & 3.27 & 1.35 \\
\hline $\mathrm{TiO}_{2}$ & 10.91 & 8.98 & 3.52 & 1.66 & 0.73 & 0.18 & 0.35 & 0.04 & 0.27 & 0.09 & 0.03 \\
\hline $\mathrm{Al}_{2} \mathrm{O}_{3}$ & 3.93 & 2.32 & 3.75 & 1.32 & 0.19 & 0.00 & 0.63 & 0.25 & 0.00 & 0.36 & 0.00 \\
\hline $\mathrm{Fe}_{2} \mathrm{O}_{3}$ & 11.12 & 11.97 & 14.73 & 18.63 & 31.82 & 2.41 & 2.83 & 1.60 & 3.54 & 2.77 & 4.69 \\
\hline $\mathrm{FeO}$ & 10.13 & 8.26 & 8.24 & 7.40 & 12.00 & 1.24 & 1.60 & 1.00 & 1.32 & 0.87 & 3.17 \\
\hline $\mathrm{MnO}$ & 0.22 & 0.25 & 0.35 & 0.54 & 0.48 & 0.18 & 0.11 & 0.15 & 0.15 & 0.12 & 0.81 \\
\hline $\mathrm{MgO}$ & 11.31 & 10.82 & 10.18 & 16.15 & 8.86 & 3.14 & 2.44 & 1.87 & 3.80 & 2.60 & 15.77 \\
\hline $\mathrm{CaO}$ & 17.30 & 19.33 & 19.73 & 16.38 & 18.60 & 48.06 & 48.26 & 51.67 & 46.53 & 48.37 & 27.94 \\
\hline $\mathrm{Na}_{2} \mathrm{O}$ & 0.63 & 0.65 & 1.14 & 0.21 & 0.36 & 0.22 & 0.5 & 0.05 & 0.20 & 0.08 & 0.05 \\
\hline $\mathrm{K}_{2} \mathrm{O}$ & 1.05 & 0.98 & 2.30 & 1.36 & 0.54 & 0.31 & 0.44 & 0.19 & 0.68 & 0.48 & 0.06 \\
\hline $\mathrm{P}_{2} \mathrm{O}_{5}$ & 0.52 & 1.01 & 5.16 & 8.63 & 6.10 & 2.27 & 3.76 & 1.06 & 2.60 & 1.93 & 2.03 \\
\hline $\mathrm{CO}_{2}$ & 0.84 & 1.15 & 6.92 & 6.30 & 13.80 & 37.08 & 33.46 & 40.96 & 35.17 & 37.82 & 41.81 \\
\hline $\mathrm{H}_{2} \mathrm{O}-$ & 0.18 & 0.24 & 0.34 & 0.40 & 0.36 & 0.22 & n.a. & n.a. & 0.27 & 0.21 & 0.24 \\
\hline LOI & 1.30 & 0.37 & 0.00 & 2.96 & 0.00 & 0 & n.a. & n.a. & 0.00 & 0.00 & 0.00 \\
\hline $\mathrm{F}$ & 0.09 & 0.08 & 0.36 & 0.54 & 0.36 & 0.19 & n.a. & n.a. & 0.24 & 0.12 & 0.16 \\
\hline $\mathrm{Cl}$ & 0.01 & 0.01 & b.d.l. & 0.00 & b.d.l. & 0.01 & n.a. & n.a. & 0.01 & 0.02 & 0.02 \\
\hline$S_{\text {tot }}$ & 0.03 & 0.32 & n.a. & 0.33 & 0.5 & 0.44 & n.a. & n.a. & 0.78 & 0.71 & 2.04 \\
\hline$-\mathrm{O}=\mathrm{F}+\mathrm{S}$ & -0.05 & -0.19 & -0.15 & -0.39 & -0.4 & -0.3 & n.a. & n.a. & -0.49 & -0.40 & -1.08 \\
\hline Total & 99.52 & 99.59 & 99.00 & 99.21 & 99.90 & 98.98 & 99.37 & 99.77 & 99.02 & 99.42 & 99.09 \\
\hline
\end{tabular}

Analyzed by: 1 - wet chemical analysis; 2 - XRF spectrometry; n.a. = not analysed.

$\mathrm{Rb}$ and Sr concentrations were determined by XRF spectrometry at the University of Brussels (ULB) and by ICP emission spectroscopy. Nd and Sm contents were obtained either by ICP-MS or by isotope dilution mass spectrometry on a VG 354 5-collector mass spectrometer at Royal Holloway, University of London (RH). Sr and Nd isotopic compositions were measured at Royal Holloway and also on a MAT 260 single collector mass spectrometer in ULB (Table 6). Initial $\mathrm{Sr}$ and $\mathrm{Nd}$ isotopic ratios were calculated at $380 \mathrm{Ma}$ using the decay constant of $1.42 \times 10^{11} \mathrm{a}^{-1}\left({ }^{87} \mathrm{Rb}\right)$ and $6.54 \times 10^{12} \mathrm{a}^{-1}\left({ }^{147} \mathrm{Sm}\right)$ (Steiger, Jager 1977). 
REE data (in ppm) of Seblyavr silicate rocks and carbonatites

\begin{tabular}{ccccccccccc}
\hline Sample & $388 / 249$ & $388 / 240$ & Sb3 & $388 / 236$ & Sb5 & $88-81$ & $91(2)-81$ & Sb4 & Sb9 & $388 / 269$ \\
\hline $\begin{array}{c}\text { Rock } \\
\text { Type }\end{array}$ & 2 & 2 & 1 & 2 & 1 & 1 & 1 & 2 & 1 & 2 \\
\hline Pa & 19.8 & 167 & 214 & 309 & 232 & 167 & 122 & 331 & 1290 & 187 \\
\hline $\mathrm{Ce}$ & 40 & 402 & 510 & 727 & 491 & 326 & 251 & 606.5 & 1510 & 406 \\
\hline $\mathrm{Pr}$ & 3.8 & 49 & 63 & 94 & 56 & 40.4 & 30.2 & 67.09 & 126 & 39 \\
\hline $\mathrm{Nd}$ & 11 & 199 & 245 & 387 & 206 & 158 & 113 & 253.03 & 321 & 122 \\
\hline $\mathrm{Sm}$ & 1.1 & 33 & 41 & 61 & 31 & 27.6 & 17.4 & 38.25 & 23 & 12 \\
\hline $\mathrm{Eu}$ & 0.32 & 9.7 & 12.2 & 17.5 & 9.3 & 8.19 & 5.05 & 10.9 & 5.6 & 3.3 \\
\hline $\mathrm{Gd}$ & 0.76 & 31 & 33 & 54 & 26 & 22.8 & 13.6 & 26.35 & 22 & 10 \\
\hline $\mathrm{Dy}$ & 0.35 & 16 & 17.7 & 25 & 13.9 & 14.1 & 8.76 & 15.62 & 4.9 & 5.4 \\
\hline $\mathrm{Ho}$ & 0.04 & 2.1 & 2.7 & 3.2 & 2.2 & 2.4 & 1.54 & 2.64 & 0.63 & 0.69 \\
\hline $\mathrm{Er}$ & 0.1 & 4.6 & 5.5 & 6.8 & 4.7 & 4.75 & 3.2 & 5.46 & 1.58 & 1.5 \\
\hline $\mathrm{Yb}$ & 0.07 & 2.7 & 2.9 & 3.5 & 2.8 & 2.27 & 2.3 & 3.24 & 0.52 & 0.8 \\
\hline $\mathrm{Lu}$ & 0.01 & 0.33 & 0.36 & 0.42 & 0.35 & 0.41 & 0.33 & 0.43 & 0.04 & 0.1 \\
\hline$(\mathrm{La} / \mathrm{Yb})_{N}$ & 189 & 41.7 & 49.3 & 59 & 55.4 & 44 & 38.1 & 68.3 & 1659 & 156.3 \\
\hline & & & & & & & & & & \\
\hline
\end{tabular}

Analysed by: 1 - ICP emission mass spectrometry (ULB); 2 - ICP atomic spectroscopy (RH).

Normalizing values for $(\mathrm{La} / \mathrm{Yb}) \mathrm{N}$ from McDonough and Sun (1995).

\section{PETROGRAPHY AND MINERAL CHEMISTRY}

The clinopyroxenites (PRX) are coarse-grained, deep green to black rocks. Prismatic, partly resorbed diopside crystals form $>70$ vol. $\%$ with $\mathrm{Mg} \#$ of around 0.88 . The interstices are filled with anhedral to subhedral perovskite and/or magnetite, Ti-rich phlogopite $(\mathrm{Mg} \#=0.85)$, amphibole, apatite and calcite. Magnetite and perovskite crystallized before phlogopite and amphibole. Secondary perovskite and titanite commonly mantle the magnetite. The clinopyroxenites have ortho- to mesocumulate textures, although the cumulate texture locally has been largely obliterated because of replacement of clinopyroxene by mica, amphibole and garnet.

The phoscorites (Ph I, Ph II, Ph III) commonly are medium- to coarse-grained massive green or grey rocks, dark due to the presence of abundant magnetite (commonly $>25$ vol.\%), with clear cumulative textures. The first stage phoscorite is composed mainly of prismatic diopside $(\mathrm{Mg \#}=0.89)$, and subhedral magnetite with small 
Isotopic measurements were made in isotopic laboratories of: ${ }^{1}, \mathrm{RH} ;{ }^{2}, \mathrm{ULB}$

\begin{tabular}{|c|c|c|c|c|c|c|c|}
\hline Sample No & Rock & $\mathrm{Rb}, \mathrm{ppm}$ & Sr, ppm & ${ }^{87} \mathrm{Sr} / 86 \mathrm{Sr}$ & $2 \mathrm{~s}$ & $\left({ }^{87} \mathrm{Sr} / 86 \mathrm{Sr}\right)_{380}$ & \\
\hline $\mathrm{Sb} 2^{2}$ & PRXp & $47^{* *}$ & $379^{* *}$ & 0.705100 & 9 & 0.70316 & \\
\hline $\mathrm{Sb}^{2}$ & $\mathrm{Ph} \mathrm{I}$ & $48^{*}$ & $1064^{*}$ & 0.704017 & 11 & 0.70331 & \\
\hline $\mathrm{Sb}^{2}$ & C I & $12^{*}$ & $5308^{*}$ & 0.703224 & 11 & 0.70319 & \\
\hline $88-81^{2}$ & C I & $12.5^{* *}$ & $4179^{* *}$ & 0.703142 & 1 & 0.70310 & \\
\hline $\mathrm{Sb} 4^{1}$ & C II & $22^{* *}$ & $5528^{* *}$ & 0.70318 & 1 & 0.70314 & \\
\hline \multirow[t]{2}{*}{$91(2)-81^{2}$} & C II & $10.5^{* *}$ & $4557^{* *}$ & 0.70329 & 1 & 0.70325 & \\
\hline & & Sm, ppm & $\mathrm{Nd}, \mathrm{ppm}$ & ${ }^{143} \mathrm{Nd} /{ }^{144} \mathrm{Nd}$ & $2 \mathrm{~s}$ & $\left({ }^{143} \mathrm{Nd} /{ }^{144} \mathrm{Nd}\right)_{380}$ & $\varepsilon^{\mathrm{Nd}}{ }_{380}$ \\
\hline $\mathrm{Sb} 2^{2}$ & $P R X p$ & 97.4 & 680 & 0.512642 & 5 & 0.512427 & 5.5 \\
\hline $\mathrm{Sb}^{2}$ & $\mathrm{Ph} \mathrm{I}$ & $41^{*}$ & $245^{*}$ & 0.512695 & 10 & 0.512443 & 5.8 \\
\hline $\mathrm{Sb}^{2}$ & C I & $31^{*}$ & $206^{*}$ & 0.512673 & 6 & 0.512447 & 5.9 \\
\hline $88-81^{2}$ & C I & 27.6 & 157 & 0.512657 & 6 & 0.512411 & 5.1 \\
\hline $\mathrm{Sb} 4^{1}$ & C II & $38.3^{*}$ & $253^{*}$ & 0.512667 & 11 & 0.512440 & 5.7 \\
\hline $91(2)-81^{2}$ & C II & 17.4 & 113 & 0.512632 & 27 & 0.512400 & 4.9 \\
\hline
\end{tabular}

* Determined by ICP emission spectroscopy in separate portion of powder.

** Determined by XRF spectrometry in separate portion of powder.

inclusions of perovskite, calzirtite and zirkelite grains. The interstices contain phlogopite, perovskite, amphibole, apatite, calcite, sulphides and fine grains of zirkelite and zircon. The diopsides are sometimes resorbed by phlogopite $(\mathrm{Mg} \#=0.86)$ and pseudomorphed by amphibole (eckermannite). Secondary zircons fill the inter-grain space and small cracks in the amphibole crystals. The second stage phoscorite consists of euhedral forsterite crystals ( $>30 \mathrm{vol} . \%$ ) pseudomorphed by serpentine, segregations of apatite ( $>20$ vol.\%) and subhedral magnetite (>20 vol.\%). The minerals are listed in the sequence of crystallization. The interstices are filled with phlogopite, calcite and sulphides. Baddeleyite occurs as euhedral crystals in the apatite segregations, growing close to magnetite. Zircon and pyrochlore are accessory phases. The third stage phoscorite is composed of subhedral magnetite ( $>35 \mathrm{vol} . \%)$, segregations of apatite (>15 vol.\%) and some primary forsterite now replaced by a fine-grained aggregate of tetraferriphlogopite $(\mathrm{Mg} \#=0.93-0.92)$ and serpentine. Euhedral baddeleyite crystals occur together with apatite and magnetite. Tetraferriphlogopite and calcite with some sulphides and rare zircon fill the interstices.

The calcite carbonatites (CI, CII and CIII) are medium- to coarse-grained rocks with a slightly banded fabric, mainly composed of anhedral calcite (> 80 vol.\%) with various amounts of silicate minerals, magnetite, sulphides, apatite and accessories (Table 2). The commonly twinned calcite crystals are closely knitted giving a consertal texture. 
Apatite in calcite carbonatites occurs as separate crystals, chains of crystals or segregations of grains. The carbonatites $\mathrm{CI}$ and $\mathrm{CII}$ are very similar one to another in terms of texture and mineral composition. The CI carbonatite contains rare grains of diopside. Both contain anhedral crystals of phlogopite, needles of amphibole (richterite in CI, arfvedsonite in CII), magnetite and sulphides. As accessories they contain fine euhedral zircon and baddeleyite crystals, with garnet in the CI carbonatite and also barite and pyrochlore in the CII. The CIII carbonatite contains tetraferriphlogopite mica, richterite and dolomite as a minor phase, pyrochlore, uranoan pyrochlore, zircon and zirkonolite as accessory minerals.

The dolomite carbonatites (DIV) are medium-grained rocks with a massive fabric and composed of anhedral dolomite grains, which differ widely in size, small rare euhedral tetraferriphlogopite $(\mathrm{Mg} \#=0.91)$, apatite, chlorite and segregations of sulphides (pyrrhotite, sphalerite, pyrite and galena) up to $5 \mathrm{~cm}$ in diameter. Pyrochlore, zircon and barite are accessories. The DIV carbonatite sample $\mathrm{Sb} 9$ has numerous cavities filled with low temperature hydrothermal minerals ancylite-(Ce), strontianite and barite (Bulakh et al. 1998).

\section{MAJOR, REE AND ISOTOPE GEOCHEMISTRY}

Most of the analysed samples are cumulates, so their chemical variations reflect the proportions of their constituent minerals (Table 4). The Seblyavr clinopyroxenites have low $\mathrm{Mg \#} \mathrm{(ca.} \mathrm{50)} \mathrm{due} \mathrm{to} \mathrm{a} \mathrm{high} \mathrm{content} \mathrm{of} \mathrm{total} \mathrm{FeO}$ that reflects their magnetite-rich

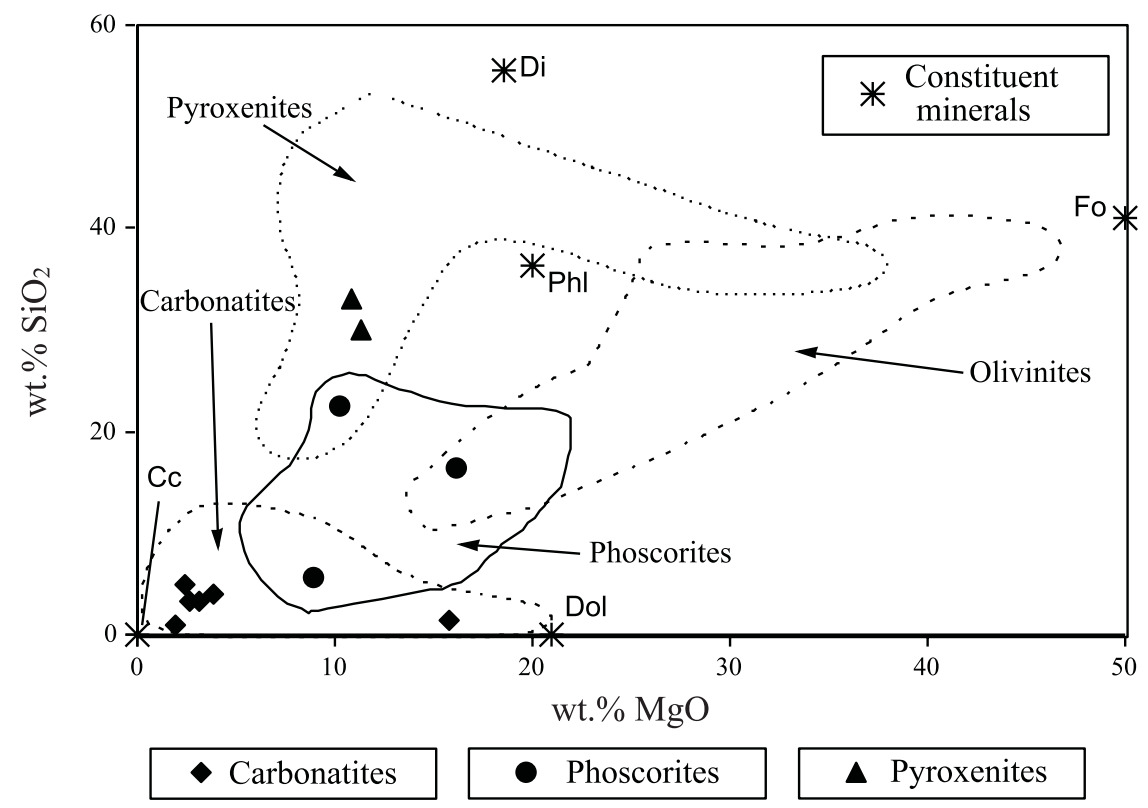

Fig. 3. Wt.\% $\mathrm{SiO}_{2}$ vs. wt.\% MgO diagram showing compositional variations of the Seblyavr rocks. Data fields for rock-types from the KACP are from Downes et al. (2005) 
modal mineralogies. The high contents of $\mathrm{CaO}(17.3-19.3 \mathrm{wt} . \%)$ are due to the abundance of clinopyroxene, whereas the high $\mathrm{TiO}_{2}$ (9-10 wt.\%) abundances can be explained by the presence of $>20 \%$ perovskite and magnetite. On a variation diagram of $\mathrm{SiO}_{2}$ vs $\mathrm{MgO}$ (Fig. 3), the clinopyroxenites fall within the field of similar rocks from elsewhere in the KACP, dominated by the composition of diopside.

Phoscorites are variable in both $\mathrm{SiO}_{2}$ and $\mathrm{MgO}$, reflecting the modal mineralogy. They show trends either to diopside or to olivine (Fig. 3). $\mathrm{SiO}_{2}$ decreases (22.4 to $5.6 \mathrm{wt} . \%$ ) and $\mathrm{Na}_{2} \mathrm{O}+\mathrm{K}_{2} \mathrm{O}$ increases ( 2.5 to $0.5 \mathrm{wt} . \%$ ) from the first to third stage, with an increase in the total $\mathrm{FeO}$ (21.5 to 40.6 wt.\%), reflecting the presence of cumulus magnetite. The $\mathrm{P}_{2} \mathrm{O}_{5}$ content in the phoscorites is 5.2 to $8.6 \mathrm{wt}$.\%, higher than those in carbonatites (1.1 to $3.8 \mathrm{wt} . \%)$, due to the higher abundance of apatite.

The Seblyavr carbonatites have generally $<5 \mathrm{wt} . \% \mathrm{SiO}_{2}$ and $<4$ wt. $\% \mathrm{MgO}$, so they plot near the calcite composition on Figure 3, although the higher $\mathrm{MgO}$ content (15.8 wt.\%) in DIV sample Sb9 reflects the presence of dolomite. Their $\mathrm{Al}_{2} \mathrm{O}_{3}, \mathrm{~K}_{2} \mathrm{O}$ and $\mathrm{Na}_{2} \mathrm{O}$ contents are low, as is characteristic of most plutonic carbonatites (Woolley, Kempe 1989). The iron content is variable depending on the amount of cumulus magnetite. Sulphur contents increase from CI to CIII ( 0.44 to $0.71 \mathrm{wt} . \%)$, being very high in DIV (2.04 wt.\%) in combination with relatively high total FeO content (7.4 wt.\%) and reflecting the abundance of pyrrhotite probably of hydrothermal origin.

All the rocks, both silicate or carbonatitic, are enriched in LREE with $(\mathrm{La} / \mathrm{Yb})_{\mathrm{N}}$ ratios generally ranging from 38 to 189 (Fig. 4). Dolomite carbonatite Sb9 with hydrothermal LREE-Sr mineralization in cavities displays an extreme $(\mathrm{La} / \mathrm{Yb})_{\mathrm{N}}$ value of 1659 and its pattern is clearly very different from those of the magmatic rocks. The clinopyroxenites show a wide variation in absolute abundances of the REE, reflecting the abundance of minor cumulus phases such as apatite and/or amphibole. REE contents tend to be highest in the apatite-rich phoscorites and calcite carbonatites. Nevertheless, the REE

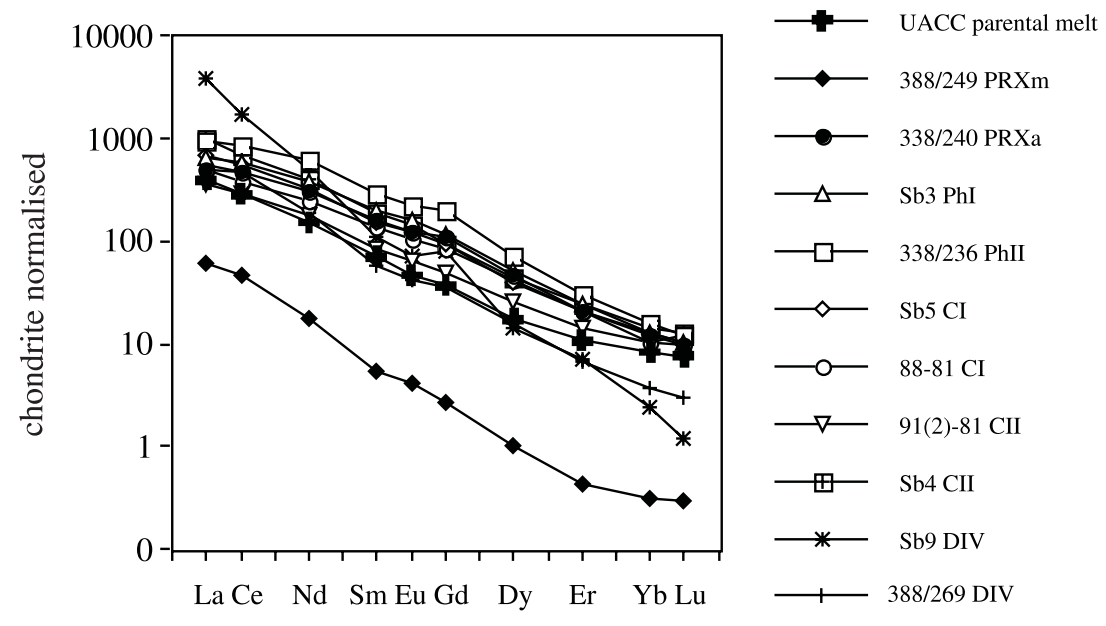

Fig. 4. Chondrite-normalized REE abundances (normalizing values from McDonough and Sun 1995).

"UACC parental melt" is the hypothetical parental melt for the KACP ultramafic alkaline and carbonatitic complexes (Downes et al. 2005) 


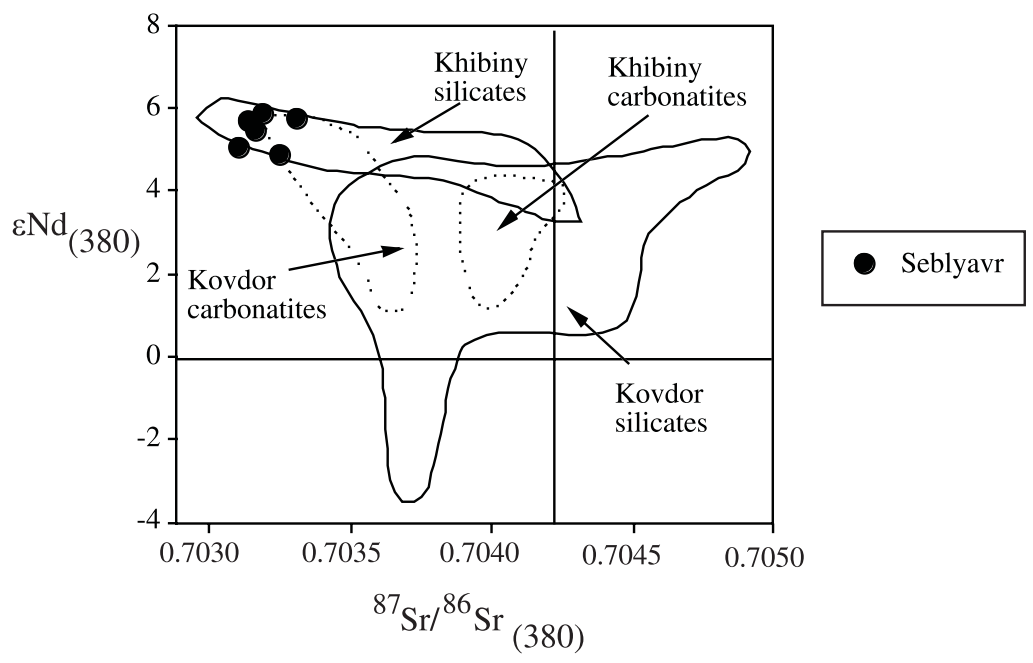

Fig. 5. Nd-Sr isotopic data for Seblyavr rocks, corrected to $380 \mathrm{Ma}$, in comparison with selected rocks from the Kola Alkaline Carbonatite Province

patterns of all of the magmatic rocks are strikingly parallel to that of the hypothetical primitive melt suggested for the KACP magmatism by Downes et al. (2005).

The $\mathrm{Sr}$ and Nd isotopic data of Seblyavr carbonatites, phoscorites and silicate rocks (Table 6) are shown on the $\varepsilon_{\mathrm{Nd}}$ vs. ${ }^{87} \mathrm{Sr} /{ }^{86} \mathrm{Sr}_{\mathrm{i}}$ diagram (Fig. 5), in which comparison is made with other Kola intrusive rocks and carbonatites (Verhulst et al. 2000; Downes et al. 2005). All rocks studied have ${ }^{87} \mathrm{Sr} / 86 \mathrm{Sr}_{380}$ and $\varepsilon_{\mathrm{Nd}}{ }^{380}$ that vary within the narrow limits of 0.7031 to 0.7033 and +4.9 to +5.9 , respectively. These values are among the most depleted of any in the KACP and resemble the more depleted end-member of the isotopic array for silicate rocks from Khibina and carbonatites from Kovdor. There is no obvious difference in isotope composition between the carbonatite and silicate rocks.

\section{DISCUSSION}

All of the Seblyavr rocks show clear compositional signatures of magmatic processes, except for the DIV carbonatite Sb9, which is dominated by hydrothermal mineralization. The main rock-types within the massif vary one from another mainly in mineral abundances (Table 2), some show clear cumulate textures, and all of them are considered to have been formed by accumulative processes rather than being simply the product of freezing of melt batches. This is reflected in their major element characteristics that are dominated by the modal variations in their constituent cumulus minerals (Fig. 3). Their compositions are similar to those of other cumulate rock-types in the KACP (Downes et al. 2005). Because the rocks are cumulates, the content of REE in the whole rock primarily reflects the modal abundance of REE-rich minerals and (to a lesser extent) the REE pattern of the melt from which they crystallized. The clinopyroxenite sample 388/249 has a much lower REE content than the other 
pyroxenites, probably because it contains much less apatite and amphibole. The remarkably parallel REE patterns of the Seblyavr samples (Fig. 4) indicate that the rocks were derived from closely related magmas or perhaps even a single parental magma similar to the hypothetical parent melt for the KACP (Downes et al. 2005). Only the late-stage DIV samples have their REE patterns with conspicuously different slopes, presumably reflecting hydrothermal processes.

The mantle origin of carbonatites is considered to be well proven, so the isotope composition of carbonatites reflects the signatures of their mantle source (Bell, Blenkinsop 1987; Kwon et al. 1989; Bailey 1993; Bell 1998; Verhulst et al. 2000). The Sr and $\mathrm{Nd}$ isotope data for Seblyavr (Table 6, Fig. 5) show that the clinopyroxenites, phoscorites and carbonatites have almost identical initial compositions $\mathrm{I}_{\mathrm{Sr}}{ }^{380}=0.7031$ to 0.7033 and $\varepsilon_{\mathrm{Nd}} 380=+4.9$ to +5.9 . This is evidence for all these rock-types being derived from the same depleted upper mantle OIB-type source and being formed as a result of differentiation and crystallization of a single melt batch. The Seblyavr rocks form a field close to the DM region, showing that crustal contamination was absent or minor. They are also identical to the most depleted end-member of the Khibina silicate magmas and the Kovdor carbonatites, indicating a widespread and persistent source composition across the KACP. However, their strongly LREE-enriched compositions indicate that metasomatism occurred in their mantle source just prior to melting.

The Seblyavr massif was intruded in a series of events (Table 1). It would be possible to interpret the range of ages as suggesting two separate periods of intrusion, but it is more likely that the older ages are due to alteration of phlogopite. The similarity in $\mathrm{Sr}-\mathrm{Nd}$ isotope systematics of all studied rocks suggests that they have been derived from a single mantle source. This depleted mantle produced magma that ranged in composition from a carbonate-bearing silicate melt to an $\mathrm{Mg}$-Ca carbonatite melt. The $\mathrm{Sr}$ and $\mathrm{Nd}$ isotope compositions provide further evidence that both silicate and phoscorite-carbonatitic rocks in a single massif can be derived from a common mantle source. Identical or close values of $\mathrm{I}_{\mathrm{Sr}}$ and $\varepsilon_{\mathrm{Nd}}$ from silicate rocks and carbonatites were reported for the Ozernaya Varaka massif (Kramm 1993; Kramm et al. 1993) and the Kontozero caldera (Arzamastsev et al. 1998). In contrast, carbonatites and silicate rocks from the Khibina massif considerably differ in $\mathrm{I}_{\mathrm{Sr}}$ and $\varepsilon_{\mathrm{Nd}}$ from each other and evolved from different mantle reservoirs (Kramm, Kogarko 1994; Zaitsev et al. 1997). From Sr isotope compositions, similar distinctions between phoscorites and silicate rocks were discovered in the Turiy Peninsula massif (Dunworth 1997). These isotopic variations provide evidence for a more complicated formation of the parental magmas for some massifs through mixing of two or more mantle components (Kramm 1993; Zaitsev, Bell 1995) or by mixing of different portions of melts under open system conditions (Verhulst et al. 2000).

\section{CONCLUSIONS}

The new mineralogical, geochemical (major elements and REE) and Sr-Nd isotope data on the Seblyavr intrusion give rise to the following conclusions: 
1. Clinopyroxenites, phoscorites and carbonatites were formed as a result of differentiation and crystallization of one batch of melt.

2. The parental melt was derived from a common depleted upper mantle source, metasomatized shortly before melting, and can be characterized by a Sr ratio of 0.7031 to 0.7033 and $\varepsilon_{\mathrm{Nd}}$ of +4.9 to +5.9 .

3. The Seblyavr intrusion provides evidence for the existence of a metasomatized subcontinental mantle, which produced magmas differing in composition from carbonate-bearing silicate melt to $\mathrm{Mg}$-Ca carbonatite melt.

Acknowledgements. We are very grateful to V.V. Balagansky for his help in preparing the manuscript, V.V. Subbotin for consultations on Seblyavr geology and mineralogy, E.A. Savchenko and A.D. Beard for microprobe work and A.V. Davydenkov for providing an appropriate work environment for E.G.B. Constructive comments and suggestions of U. Kramm greatly improved the paper. Petrographic, mineralogical and geochemical studies were supported by INTAS (grant 94-2621) to E.G.B. and D.D., EUROPROBE and an RBFR (grant 00-05-64174) to E.G.B. The mass spectrometric measurements were supported in Brussels by FNRS-FRFC grants to D.D. A NERC grant to H.D. and E.G.B. supported ICP-AES measurements in Royal Holloway. Isotope facilities at Royal Holloway were supported by ULIRS.

\section{REFERENCES}

ARZAMASTSEV A.A., ARZAMASTSEVA L.V., BELYATSKY B.V., 1998: Initial alkaline volcanism of the Palaeozoic tectonic and magmatic activation in the North-Eastern Fennoscandia: geochemical features and petrological consequences. Petrology 6, 316-336 (in Russian).

BAILEY D.K., 1993: Carbonatite magmas. Journal of Geological Society (London) 150, 637-651.

BELL K., BLENKINSOP J., 1987:Archean depleted mantle: Evidence from Nd and Sr initial isotopic ratios of carbonatites. Geochimica and Cosmochimica Acta 51, 291-298.

BELL K., 1998: Radiogenic isotope composition on relationships between carbonatites and associated silicate rocks - a brief review. Journal of Petrology 39, 1987-1996.

BULAKH A.G., ABAKUMOVA N.B., 1960: The Seblyavr massif of ultrabasic and alkaline rocks and carbonatites (Kola Peninsula). Sovetskaya Geologiya 5, 47-60 (in Russian).

BULAKH A.G., LE BAS M.J., WALL F., ZAITSEV A.N., 1998: Ancylite-bearing carbonatites of the Seblyavr massif, Kola Peninsula, Russia. Neues Jahrbuch für Mineralogie, Monatshefte 4, 171-192.

DOWNES H., BALAGANSKAYA E., BEARD A., LIFEROVICH R., DEMAIFFE D., 2005: Petrogenetic processes in the ultramafic, alkaline and carbonatitic magmatism in the Kola Alkaline Province: a review. Lithos $85,48-75$.

DUNWORTH E.A., 1997: The Turiy Massif, Kola Peninsula, Russia: open system disequilibrium. PhD thesis, Carleton University, Ottawa, Canada. 488pp.

EGOROV L.S., 1993: Phoscorites of the Maymecha-Kotuy ijolite-carbonatite association. International Geology Review 35, 346-358.

GOGOL O.V., BAYANOVA T.B., BALAGANSKAYA E.G., DELENITSIN A.A., 1998: New evidence on the duration of alkaline magmatism of the Kola region (Russia) based on Rb-Sr and U-Pb isotope data. ICOG-9, Beijing, China. Abstracts. Chinese Science Bulletin 43, 45.

GOGOL O.V., DELENITSIN A.A., 1999: New Rb-Sr data for Kola alkaline province. In: Proceedings of the 10th Kratz Conference, Apatity, 43-47 (in Russian).

GOGOL O.V., BAYANOVA T.B., DELENITSIN A.A.,: 2000. Stages of the carbonatite formation on the sample of the Seblyavr massif (according to isotope data). In: Proceedings of the XIX seminar "Geochemistry of the magmatic rocks", Moscow, 45-46 (in Russian).

KOGARKO L.N., KONONOVA V.A., ORLOVA M.P., WOOLLEY A.R., 1995: Alkaline rocks and carbonatites of the world. Part 2. Former USSR. Chapman and Hall, London, $225 \mathrm{pp}$. 
KRAMM U., 1993: Mantle components of carbonatites from the Kola Alkaline Province, Russia and Finland: A Nd-Sr study. European Journal of Mineralogy 5, 985-989.

KRAMM U., KOGARKO, L.N., 1994: Nd and Sr isotope signatures of the Khibina and Lovozero agpaitic centres, Kola Alkaline Province, Russia. Lithos 32, 225-242.

KRAMM U., KOGARKO L.N., KONONOVA V.A., VARTIAINEN H., 1993: The Kola Alkaline Province of the CIS and Finland: Precise Rb-Sr ages define 380-360 Ma age range for all magmatism. Lithos 30, 33-44.

KRAMM U., SINDERN S., 2004: Timing of Kola ultrabasic alkaline, alkaline and phoscorite carbonatite magmatism. In: Wall F., Zaitsev A.N. (eds) Phoscorites and carbonatites from Mantle to Mine. Mineralogical Society Series 10, Chapter 3. pp. 75-97.

KUKHARENKO A.A., ORLOVA M.P., BULAKH A.G., BAGDASAROV E.A., RIMSKAYA-KORSAKOVA O.M., NEFEDOV E.I., IL'INSKY G.A., SERGEEV A.S., ABAKUMOVA N.B., 1965: The Caledonian complex of ultrabasic, alkaline rocks and carbonatites of the Kola Peninsula and northern Karelia. Moscow, Nedra, 550 pp. (in Russian).

KWON S.-T., TILTON G.R., GRUNENFELDER M.H., 1989: Lead isotope relationships in carbonatites and alkaline complexes: an overview. In: K. Bell (ed.) Carbonatites: Genesis and Evolution. Unwin Hyman, London, pp.360-386.

LAPIN A.V., 1979: Mineral parageneses of apatite ores and carbonatites of the Seblyavr massif. International Geology Review 21, 1043-1052.

McDONOUGH W.F., SUN S.-S., 1995: The composition of the Earth. Chemical Geology 120, 223-253.

STEIGER R.H., JAGER E., 1977: Subcommission on geochronology: convention on the use of decay constants in geo- and cosmochronology. Earth and Planetary Science Letters 36, 359-362.

SUBBOTIN V.V., 1998: Mineralogy of zirconium and niobium in rocks of carbonatite series of alkaline-ultramafic massifs of the Kola Peninsula. Extended abstract of Ph.D. dissertation. St.-Petersburg, 20 pp. (in Russian).

SUBBOTIN V.V., MIKHAELIS S.A., 1986: Genetical types of apatite ores of the Seblyavr complex deposit. In: O.B. Dudkin, S.I. Makiyevsky, V.Ya. Evzerov (eds) Deposits of non-metallic raw materials of the Kola Peninsula. Kola Branch of the USSR Acad. Sci., Apatity, 27-35 (in Russian).

TOMKEIEFF S.I., WALTON E.K., RANDALL B.A.O., BATTEY M.H., TOMKEIEFF O., 1983: Dictionary of Petrology. John Wiley, $680 \mathrm{pp}$.

VERHULST A., BALAGANSKAYA E., KIRNARSKY YU., DEMAIFFE D., 2000: Petrological and geochemical (trace elements and Sr-Nd isotopes) characteristics of the Paleozoic Kovdor ultramafic, alkaline and carbonatite intrusion (Kola Peninsula, NW Russia). Lithos 51, 1-25.

WOOLLEY A.R.., 1989: The spatial and temporal distribution of carbonatites. In: Bell K. (ed.) Carbonatites: Genesis and Evolution. Unwin Hyman, London, 15-37.

WOOLLEY A.R., KEMPE D.R.C., 1989: Carbonatites: nomenclature, average chemical compositions and element distribution. In: Bell K. (ed.) Carbonatites: Genesis and Evolution. Unwin Hyman, London, $1-14$.

ZAITSEV A., BELL K., 1995: Sr and Nd isotope data of apatite, calcite and dolomite as indicators of source, and the relationships of phoscorites and carbonatites from the Kovdor massif, Kola peninsula, Russia. Contributions to Mineralogy and Petrology 121, 324-335.

ZAITSEV A.N., BELL K., WALL F., LE BAS M.J., 1997: Alkaline-rare earth carbonates from carbonatites of Khibina massif: Mineralogy and genesis. Doklady Akademii Nauk 355, 241-245 (in Russian). 
Elena G. BALAGANSKAYA, Hilary DOWNES, Daniel DEMAIFFE

\section{REE i izotopy Sr-Nd w klinopiroksenitach, foskorytach i karbonatytach masywu sebliawrskiego z Półwyspu Kola (Rosja)}

\section{Streszczenie}

Petrograficzna charakterystyka dewońskich klinopiroksenitów, foskorytów i karbonatytów z masywu sebliawrskiego na Półwyspie Kola (Rosja) wskazuje, że skały te są kumulatami. Ich skład chemiczny (zarówno pierwiastki główne jak i pierwiastki ziem rzadkich) stanowi zapis procesów akumulacyjnych i wynika ze zmieszania głównych minerałów skałotwórczych i faz akcesorycznych. Wszystkie analizowane skały masywu sebliawrskiego są silnie wzbogacone w LREE, a ich stosunek $(\mathrm{La} / \mathrm{Yb})_{\mathrm{N}}$ waha się przeważnie pomiędzy 38 a 189. Skrajnie wysoki stosunek $(\mathrm{La} / \mathrm{Yb})_{\mathrm{N}}$ równy 1659 zanotowano $\mathrm{w}$ dolomitowym karbonatycie, zawierającym hydrotermalną mineralizację LREE-Sr. Takie karbonatyty zostały utworzone w końcowych etapach powstawania masywu dzięki właśnie procesom hydrotermalnym, a nie magmowym. Próbki reprezentujące skały magmowe masywu wykazują początkowe stosunki izotopów strontu ${ }^{87} \mathrm{Sr} /{ }^{86} \mathrm{Sr}$ i wartości parametru $\varepsilon_{\mathrm{Nd}}$ zawarte w wąskich przedziałach, odpowiednio od 0,7031 do 0,7033 i od $+4,9$ do $+5,9$. Upoważnia to do sformułowania wniosku, że badane klinopiroksenity, foskoryty i karbonatyty utworzyły się w wyniku dyferencjacji i krystalizacji pojedynczej porcji stopu magmowego. Ten macierzysty stop został wygenerowany ze zubożonego górnego płaszcza, a źródłowy materiał uległ metasomatozie jeszcze przed momentem stopienia. 